\title{
The strength of the biotic compartment in retaining nitrogen additions prevents nitrogen losses from a Mediterranean maquis
}

\author{
T. Dias ${ }^{1}$, M. A. Martins-Loução ${ }^{1}$, L. Sheppard ${ }^{2}$, and C. Cruz ${ }^{1}$ \\ ${ }^{1}$ Universidade de Lisboa, Faculdade de Ciências, Centro de Biologia Ambiental (CBA), Campo Grande, \\ 1749-016 Lisboa, Portugal \\ ${ }^{2}$ Centre of Ecology and Hydrology (CEH), Bush Estate, Penicuik, EH26 OQB, UK
}

Correspondence to: T. Dias (mtdias@fc.ul.pt)

Received: 7 July 2011 - Published in Biogeosciences Discuss.: 9 August 2011

Revised: 7 November 2011 - Accepted: 20 December 2011 - Published: 11 January 2012

\begin{abstract}
Nitrogen (N) is one of the nutrients most limiting to ecosystem productivity. However, $\mathrm{N}$ availability is increasing globally, which may affect ecosystem functions and stability. To understand the role of each ecosystem compartment in the cycling of increased $\mathrm{N}$, we studied the initial response of a nutrient-poor ecosystem, a Mediterranean maquis, to increased $\mathrm{N}$ deposition. $\mathrm{N}$ availability (dose and form) was modified by three $\mathrm{N}$ additions over the year (middle autumn/winter, spring and summer). Soil inorganic $\mathrm{N}$ pools (nitrate in particular) strongly reflected the $\mathrm{N}$ additions in autumn, almost matching the total $\mathrm{N}$ added over the three additions. Cistus ladanifer, the dominant plant species, responded to the increased $\mathrm{N}$ (cover and $\mathrm{N}$ concentration in leaves and litter). Given that leaf shedding occurs in the summer, the importance of this $\mathrm{N}$ pool returning to the soil through litter decomposition on the total soil inorganic $\mathrm{N}$ in autumn was investigated. Data suggest that living plants and litter have a crucial role in preventing $\mathrm{N}$ losses from Mediterranean maquis. This is the first integrated field study on how European Mediterranean ecosystems retain increased $\mathrm{N}$ of different forms and doses, however longer-term studies are needed to explore the generality of this study's observations.
\end{abstract}

\section{Introduction}

Temporal patterns of inorganic nitrogen $(\mathrm{N})$ turnover and plant growth can influence important aspects of plant community and ecosystem dynamics; e.g. N losses, plant productivity, community composition, changes in $\mathrm{N}$ and/or phosphorus (P) limitation, decomposition rates and $\mathrm{N}$ niche complementarity (Augustine and McNaughton, 2004). Anthropogenic activities have led to global $\mathrm{N}$ enrichment (Galloway et al., 2008), threatening ecosystems at local, regional and global scales (Cassman et al., 2003), since demand has become decoupled from $\mathrm{N}$ availability. Nutrient availability is a key determinant of ecosystem function and stability (Bobbink et al., 1998; Phoenix et al., 2006). When N availability exceeds an ecosystem's $\mathrm{N}$ retention capacity, a shift from a closed internal $\mathrm{N}$ cycle to an open and leaky cycle occurs, with the excess $\mathrm{N}$ being leached and/or emitted from the ecosystem (de Schrijver et al., 2008). Most research on the effects of $\mathrm{N}$ enrichment on ecosystems has focused on temperate synchronous systems (availability of resources coincides with plant growth) from northern Europe and America (Bobbink et al., 2010; Phoenix et al., 2006). There are some documented studies on asynchronous temperate ecosystems (e.g. in alpine tundra there are large increases in the inorganic $\mathrm{N}$ pool during snowmelt - Brooks et al.,1998 - and the highest rates of $\mathrm{N}$ mineralization occur during late summer or early fall, after plant senescence - Jaeger et al., 1999). However, these are exceptions and not the most common situation (Augustine and McNaughton, 2004). Therefore not much is known about asynchronous ecosystems (availability of distinct resources and plant growth do not occur at the same time) such as those in Mediterranean regions (Jackson et al., 1988). Mediterranean-type ecosystems occur worldwide and are a product of the Mediterranean climate: hot dry summers, and mild wet winters (Rivas-Martínez et al., 2004). The few studies of the $\mathrm{N}$ retention capacity of Mediterraneantype ecosystems have been made in California (e.g. Holub and Lajtha, 2004), while, as far as we are aware, none have been made of the Mediterranean Basin.

We hypothesize that the mild temperatures and less limiting water availabilities, which result in intense biological activity during the Mediterranean spring, coincide with periods of low soil inorganic $\mathrm{N}$ pools. During this period, most additional $\mathrm{N}$ is likely to be taken up by plants and microorganisms, and retained within the ecosystem's biotic compartment. However, during the dry summer, a significant 
proportion of the $\mathrm{N}$ will return to the soil through leaf shedding. In autumn, when water no longer limits biological activity, $\mathrm{N}$ returns to the inorganic form through decomposition processes. As a result, soil inorganic $\mathrm{N}$ pools are expected to be the highest in autumn. For this reason we studied soil inorganic $\mathrm{N}$ over time, plant community and the $\mathrm{N}$ stored in plants and litter in a Mediterranean maquis in response to $\mathrm{N}$ additions. Our objective was to evaluate the short-term $\mathrm{N}$ retention capacity of a Mediterranean maquis (i.e. a type of Mediterranean habitat that comprises closed vegetation, usually with $100 \%$ cover, mainly shrubs with few annuals and some geophytes, trees are nearly always present, some of which may be in shrub form) and understand which ecosystem compartments are involved in the cycling of the increased $\mathrm{N}$ in such an asynchronous ecosystem. Specifically, we examined relationships between the $\mathrm{N}$ driven response of $\mathrm{N}$ concentration in the soil, leaves and litter through two consecutive springs (2007 and 2008).

\section{Material and methods}

\subsection{Study site}

The study site $\left(38^{\circ} 29^{\prime} \mathrm{N}-9^{\circ} 01^{\prime} \mathrm{W}\right)$ is in Serra da Arrábida in the Arrábida Natural Park, south of Lisbon, Portugal (a Natura 2000 site - PTCON0010 Arrábida/Espichel). It is located in a sub-humid thermomediterranean bioclimatic domain (Rivas-Martínez et al., 2004). According to records (1971-2000 - Instituto Nacional de Meteorologia e Geofísica), mean annual precipitation is $730 \mathrm{~mm}$; mean maximum temperature, $27.8^{\circ} \mathrm{C}$ (August); and mean minimum temperature, $8.1{ }^{\circ} \mathrm{C}$ (January). Estimated background $\mathrm{N}$ deposition is $5.2 \mathrm{~kg} \mathrm{ha}^{-1} \mathrm{yr}^{-1}\left(2.9 \mathrm{~kg} \mathrm{NO}_{\mathrm{x}}+2.3 \mathrm{~kg} \mathrm{NH}_{\mathrm{y}}-\right.$ http://webdab.emep.int/Unified_Model_Results/).

The study site is located on a southeast-facing slope (5\%) at $130 \mathrm{~m}$ a.s.l. that is protected from public access and has not been affected by human activity in recent years. Soil is skeletal $(15 \mathrm{~cm}$ depth) so that true profiles cannot be discerned and soil density is $1.3 \mathrm{~g} \mathrm{~cm}^{-3}$. Silt predominates in the soil $(50 \%)$, while sand and clay contents are $32 \%$ and $18 \%$, respectively (silt-sand-loam texture). The vegetation consists of a dense maquis (Eunis class F5.2 - Mediterranean maquis), which developed after a fire event (summer 2003) four years before the first $\mathrm{N}$ addition. The vegetation is dominated by summer semi-deciduous species which exhibit leaf dimorphism, shedding a large fraction of their leaves and twigs in the summer, and their development is coupled to water availability in the upper soil layers (Correia and Catarino, 1994; Cruz et al., 2008). At the moment, the dominant plant species is a Cistaceae, Cistus ladanifer L. (Dias et al., 2011). Other abundant plant species include Erica scoparia L. (Ericaceae), Calluna vulgaris (L.) Hull (Ericaceae), Genista triacanthos Brot. (Fabaceae), Ulex densus Welw. ex Webb (Fabaceae), Dittrichia viscosa L. (Asteraceae), and Myrtus communis L. (Myrtaceae). Herbaceous species comprise $\approx 10 \%$ of the total plant cover, of which many are annual plants.

\subsection{Experimental design and fertilization schedule}

The criteria for choosing the $\mathrm{N}$ doses and forms used in the experiment were: (a) $\mathrm{N}$ doses lower than the $\mathrm{N}$ deposition reported for other areas in Mediterranean-type ecosystems (145 $\mathrm{kg} \mathrm{Nha}^{-1} \mathrm{yr}^{-1}$ - Fenn et al., 2003; Meixner and Fenn, 2004) but high enough to establish "worst case" scenarios of $\mathrm{N}$ enrichment in this type of habitat; and (b) mimic the most likely $\mathrm{N}$ pollution scenarios in the experimental area, i.e. combined inputs from urban/industrial sites and agricultural (addition of nitrate and ammonium) and predominantly agricultural sources (addition of ammonium). Therefore, $\mathrm{N}$ availability was modified by the addition of 40 and $80 \mathrm{~kg} \mathrm{Nha}^{-1} \mathrm{yr}^{-1}$ in the form of $\mathrm{NH}_{4} \mathrm{NO}_{3}$ (doses designated $40 \mathrm{AN}$ and $80 \mathrm{AN}$ ) and $40 \mathrm{~kg} \mathrm{Nha}^{-1} \mathrm{yr}^{-1}$ as a $1: 1$ mixture of $\mathrm{N}-\mathrm{NH}_{4} \mathrm{Cl}$ and $\mathrm{N}-\left(\mathrm{NH}_{4}\right)_{2} \mathrm{SO}_{4}$ (designated $40 \mathrm{~A}$ ). Control plots were not fertilized. Beginning in January 2007, the dry $\mathrm{N}$ salts were homogenously added, by hand, in three equal applications over a year: middle autumn/winter, spring and summer. The $\mathrm{N}$ granules dissolved rapidly (1-7 days depending on the $\mathrm{N}$ addition period). $\mathrm{N}$ additions were scheduled so that no precipitation was predicted for at least one week after the $\mathrm{N}$ addition. Data reported in the present paper is based on four $\mathrm{N}$ additions that took place in January, April and August 2007; and January 2008, always following the corresponding soil sampling. Each treatment was replicated three times, 3 plots each of $400 \mathrm{~m}^{2}$. In order to restrict boundary effects and dilution processes, all measurements, analyses and sample collection were performed within an internal $100 \mathrm{~m}^{2}$ square. To prevent $\mathrm{N}$ "contamination" through runoff from N-plots, the experimental plots were distributed in three rows along the $5 \%$ slope, with the controls being located in the top row.

\subsection{Soil and plant sampling and plant assessment}

Soil was sampled from the four corners and the centre of the internal $100 \mathrm{~m}^{2}$ square of each plot. Soil samples $(2 \mathrm{~cm}$ diameter and $15 \mathrm{~cm}$ depth) were removed, sieved $(2 \mathrm{~mm})$ and stored at $4{ }^{\circ} \mathrm{C}$ until analysis. Sampling took place in May, August and October 2007; and February and April 2008, corresponding to the distinct seasons. Individual soil samples (five per plot) were used to determine soil $\mathrm{pH}$, moisture and concentrations of nitrate $\left(\mathrm{N}^{-\mathrm{NO}_{3}^{-}}\right)$, ammonium $(\mathrm{N}-$ $\mathrm{NH}_{4}^{+}$) and inorganic $\mathrm{N}$. Bulk soil samples (equal mixtures of the five soil samples from each experimental plot) collected in May 2007 and April 2008 were used for soil characterization (Table 1, see below for methods).

The vegetation at the study site was assessed within one $5 \times 5 \mathrm{~m}$ square per plot (within the internal $100 \mathrm{~m}^{2}$ ) during spring (June 2007, May 2008). C. ladanifer plant cover 
Table 1. Soil surface $(0-15 \mathrm{~cm})$ properties $(\mathrm{N}$, phosphorus $-\mathrm{P}$, potassium $-\mathrm{K}$, magnesium $-\mathrm{Mg}-$ and organic matter concentrations - OM - and $\mathrm{pH}$ ) at the first (May 2007) and second (April 2008) springs after the beginning of the experiment according to the distinct $\mathrm{N}$ additions (Control, $40 \mathrm{~A}, 40 \mathrm{AN}$ and $80 \mathrm{AN})$.

\begin{tabular}{lccccccc}
\hline $\begin{array}{l}\text { Soil } \\
\text { properties }\end{array}$ & & $\begin{array}{c}\mathrm{N} \\
\left(\mathrm{mg} \mathrm{g}^{-1}\right)\end{array}$ & $\begin{array}{c}\mathrm{P}^{*} \\
\left(\mathrm{~g} \mathrm{~g}^{-1}\right)\end{array}$ & $\begin{array}{c}\mathrm{K} \\
\left(\mu \mathrm{g} \mathrm{g}^{-1}\right)\end{array}$ & $\begin{array}{c}\mathrm{Mg}^{*} \\
\left(\mu \mathrm{g} \mathrm{g}^{-1}\right)\end{array}$ & $\begin{array}{c}\mathrm{OM} \\
\left(\mathrm{mg} \mathrm{g}^{-1}\right)\end{array}$ & $\begin{array}{c}\mathrm{pH}^{*} \\
\left(\mathrm{H}_{2} \mathrm{O}\right)\end{array}$ \\
\hline \multirow{2}{*}{ Control } & 2007 & $0.9 \pm 0.2$ & $8.0 \pm 3.1$ & $115 \pm 22$ & $126 \pm 19$ & $57 \pm 1$ & $5.8 \pm 0.2$ \\
& 2008 & $1.0 \pm 0.1$ & $5.0 \pm 1.2$ & $98 \pm 21$ & $77 \pm 13$ & $58 \pm 0$ & $5.5 \pm 0.1$ \\
\hline \multirow{2}{*}{$40 \mathrm{~A}$} & 2007 & $1.0 \pm 0.2$ & $5.3 \pm 1.3$ & $178 \pm 29$ & $135 \pm 11$ & $60 \pm 0$ & $6.5 \pm 0.3$ \\
& 2008 & $1.1 \pm 0.1$ & $3.3 \pm 0.3$ & $118 \pm 30$ & $95 \pm 7$ & $57 \pm 1$ & $5.4 \pm 0.2$ \\
\hline \multirow{2}{*}{$40 \mathrm{AN}$} & 2007 & $1.0 \pm 0.1$ & $7.0 \pm 1.5$ & $133 \pm 3$ & $117 \pm 9$ & $64 \pm 0$ & $6.3 \pm 0$ \\
& 2008 & $1.3 \pm 0$ & $4.0 \pm 0.6$ & $132 \pm 22$ & $89 \pm 4$ & $60 \pm 0$ & $5.6 \pm 0.1$ \\
\hline \multirow{2}{*}{$80 \mathrm{AN}$} & 2007 & $1.2 \pm 0.3$ & $7.3 \pm 2.8$ & $151 \pm 37$ & $137 \pm 18$ & $70 \pm 1$ & $6.7 \pm 0.3$ \\
& 2008 & $1.2 \pm 0.2$ & $4.7 \pm 1.2$ & $141 \pm 25$ & $88 \pm 1$ & $69 \pm 1$ & $5.9 \pm 0.2$ \\
\hline
\end{tabular}

${ }^{*}$ Refers to statistically significant differences between the two years; there were no significant interactions between treatment and time $(p<0.01)$. Values represent the mean $(n=3$ experimental plots per treatment) \pm SE.

was calculated from the total projected crown area (calculated from two perpendicular diameters, assuming elliptical shape).

C. ladanifer's leaves were sampled in the spring. Samples consisted of twigs containing approximately 4-5 pairs of fully expanded leaves. One twig per plant was sampled from ten random C. ladanifer plants within the internal $100 \mathrm{~m}^{2}$ square. The leaves from the ten twigs were bulked to form one composite sample per plot. Litter was sampled near to each of the five soil sampling points in each plot. Litter sampling took place in the summer. Only leaf litter from C. ladanifer was analyzed.

\subsection{Chemical analysis}

From each individual soil sample (five per plot and per sampling time), $10 \mathrm{~g}$ fresh weight (fwt) of soil were used to gravimetrically determine soil water content (Kern EG300 3M). Five $\mathrm{g}$ (fwt) of soil were used to prepare soil water extracts $(1: 10-$ weight/volume). Soil extracts were shaken (Cassel Agitator, $600 \mathrm{rpm}$ ) for one hour at room temperature, centrifuged (Eppendorf Centrifuge 5403) at $5000 \mathrm{~g}$ for $20 \mathrm{~min}$ at $4^{\circ} \mathrm{C}$. The supernatant was collected and analyzed colorimetrically (spectrophotometer Tecan Spectra Rainbow A-5082) for nitrate (Matsumura and Witjaksono, 1999), ammonium (Cruz and Martins-Loução, 2000), and for soil pH (Crison micro $\mathrm{pH}$ 2002). Soil inorganic $\mathrm{N}$ was the sum of the water extracted $\mathrm{N}_{-} \mathrm{NH}_{4}^{+}$and $\mathrm{N}-\mathrm{NO}_{3}^{-}$, and was expressed as $\mu \mathrm{g} \mathrm{N}$ per $\mathrm{g}$ of dry soil. The bulk soil samples used for determining organic matter and concentrations of total $\mathrm{N}$ and extractable $\mathrm{P}$, potassium $(\mathrm{K})$ and magnesium $(\mathrm{Mg})$ were dried at $35^{\circ} \mathrm{C}$ until constant dry weight (dwt). Organic matter was determined according to ISO standard 10694 by loss on ignition overnight at $600^{\circ} \mathrm{C}$ (Nabertherm L3/11/C6). Analysis of total $\mathrm{N}$ was carried out according to ISO standard 13878 by dry combustion using an elemental analyzer (Leco CNS). Phosphorous and potassium were quantified by a modification of the Egner-Riehm method using plasma emission spectrophotometer with an optical detector (ICP-OES), following extraction using ammonium lactate $0.1 \mathrm{M}$ and acetic acid 0.4 M, pH 3.65-3.75. Mg was extracted with ammonium acetate $1 \mathrm{M}, \mathrm{pH} 7$ and quantified by atomic absorption spectrophotometry with flame atomization. Leaf and leaf litter samples were dried at $60^{\circ} \mathrm{C}$, ground (MM 2000) and analyzed for total $\mathrm{N}$ and carbon $(\mathrm{C}-$ the same procedure as for soil samples).

\subsection{Calculations}

Changes in the cover of Cistus ladanifer over time $\left(t_{0}, t_{1}\right)$ were calculated according to Sheppard et al. (2008) as follows:

Changes over time $(\%)=\frac{\left(\text { Parameter }_{1}-\text { Parameter }_{0}\right)}{\left(\text { Parameter }_{1}+\text { Parameter }_{0}\right) / 2} \times 100$

Changes in the treatments $\left(m_{n}\right)$ in relation to the control $\left(M_{\mathrm{C}}\right)$ were calculated as follows:

Changes in relation to the control $\left(\mu \mathrm{g} \mathrm{g}^{-1}\right)=m_{n}-M_{\mathrm{C}}$

where " $m$ " corresponds to each individual value (e.g. concentration of $\mathrm{N}$ as soil inorganic $\mathrm{N}$ and litter $\mathrm{N}$ ); " $M_{\mathrm{C}}$ " corresponds to the mean value of the control for each parameter; and " $n$ " corresponds to the distinct experimental plots.

Transformation of the applied $\mathrm{N}$ doses into soil inorganic $\mathrm{N}$ concentrations $\left(\mu \mathrm{g} \mathrm{N} \mathrm{g}^{-1} \mathrm{dwt}\right.$ ) was based on the following soil characteristics: $15 \mathrm{~cm}$ depth and $1.3 \mathrm{~g} \mathrm{~cm}^{-3}$ of density, resulting in $\sim 2000 \mathrm{t}$ of soil per ha. Therefore, the addition of 40 and $80 \mathrm{~kg} \mathrm{~N}$ per ha corresponded to doses of 20 and $40 \mu \mathrm{g} \mathrm{N} \mathrm{g}^{-1}$, respectively. The transformation of the applied $\mathrm{N}$ doses into soil inorganic $\mathrm{N}$ concentrations will be referred 
to as "total $\mathrm{N}$ added", while the concentration of soil inorganic $\mathrm{N}$ in relation to the control determined in autumn will be referred to as "measured N".

The possible contributions to the soil inorganic $\mathrm{N}$ concentration determined in autumn were identified as: inorganic $\mathrm{N}$ present in the soil in the previous season - $[\mathrm{N}]$ summer; the subsequent $\mathrm{N}$ addition $-[\mathrm{N}]$ addition; and the extra $\mathrm{N}$ present in the litter (in relation to the control) which was shed during the summer $-[\mathrm{N}]$ litter. The $[\mathrm{N}]$ addition and the $[\mathrm{N}]$ litter were also transformed into soil inorganic $\mathrm{N}$ in the soil $\left(\mu \mathrm{g} \mathrm{g}^{-1}\right.$ soil dwt). The effects of the $\mathrm{N}$ additions on the three contributors were then compared to the control. The changes of litter $\mathrm{N}$ concentration in relation to the control were estimated assuming an annual litter production of $2.3 \mathrm{tha}^{-1}$ in a Mediterranean maquis (Schultz, 2002). Then we calculated the sum of the soil inorganic $\mathrm{N}$ determined in the summer, the summer $\mathrm{N}$ application and the $\mathrm{N}$ contained in the litter ("calculated N").

\subsection{Statistics}

Summary statistics of soil and plant parameters were compared for the different treatments. The repeated measures test (General Linear Model) was applied to assess the existence of significant interactions between time and treatment for soil and plant parameters and differences per treatment in leaf and litter parameters were analyzed by a one-way ANOVA. In both cases, these were followed by a Bonferroni test ( $p<0.05$ for all comparisons except for the changes in $C$. ladanifer cover $p<0.1$ ), or by a Games-Howell test whenever homogeneity of variances was not confirmed by a Levene's test. Differences between "total $\mathrm{N}$ added" and "measured N" and between "measured N" and the "calculated N" were analyzed by the t-student test $(p<0.01)$. In all cases, preliminary analyses were performed to ensure that there was no violation of the assumptions regarding the tests' application. SPSS software, version 19.0, was used for all tests.

\section{Results}

\subsection{Soil responses to $\mathbf{N}$ additions}

In the first spring after the beginning of the experiment (2007), concentrations of $\mathrm{N}, \mathrm{P}, \mathrm{K}$ and $\mathrm{Mg}$ in the soil were similar irrespective of the treatment (Table 1); the soil was very poor in $\mathrm{N}$ and $\mathrm{P}$. Soil analyses in the first and second springs after the beginning of the $\mathrm{N}$ additions showed that total $\mathrm{N}$ concentrations were not related to the applied $\mathrm{N}$ doses $\left(0,40\right.$ or $\left.80 \mathrm{~kg} \mathrm{Nha}^{-1} \mathrm{yr}^{-1}\right)$ since they were similar for all treatments. In contrast, soil $\mathrm{P}$ and $\mathrm{Mg}$ had decreased significantly by the second spring irrespective of the treatment. Although not significantly different, the decrease in $\mathrm{K}$ concentrations was most pronounced in $40 \mathrm{~A}$ plots. The $\mathrm{K}$ and $\mathrm{Mg}$ concentrations were still within the range normally found in agricultural soils, therefore not expected to be limiting. Soil organic matter in springs 2007 and 2008 were similar, while soil $\mathrm{pH}$ (in water) decreased in the second spring.

Soil total $\mathrm{N}$, inorganic $\mathrm{N}, \mathrm{NO}_{3}^{-}$and $\mathrm{NH}_{4}^{+}$concentrations in spring 2007 and 2008 were not related to the treatments. On the first sampling occasion (May 2007), the $\mathrm{N}$-plots had only received $1 / 3$ of the annual dose: $40 \mathrm{~A}$ and $40 \mathrm{AN} \approx 13 \mathrm{~kg} \mathrm{Nha}^{-1}$ and $80 \mathrm{AN} \approx 27 \mathrm{~kg} \mathrm{Nha}^{-1}$, but by spring 2008 , the fertilized plots had received $4 / 3$ of the annual dose: $40 \mathrm{~A}$ and $40 \mathrm{AN} \approx 53 \mathrm{~kg} \mathrm{Nha}^{-1}$ and $80 \mathrm{AN} \approx 107 \mathrm{~kg} \mathrm{Nha}^{-1}$.

However, when the concentrations of soil inorganic $\mathrm{N}$ and $\mathrm{NO}_{3}^{-}$were determined in the summer, autumn and winter between the two springs, it could be seen that in autumn (late October 2007) they reflected the $\mathrm{N}$ added to the system (Fig. 1). $\mathrm{NO}_{3}^{-}$was the predominant form of inorganic $\mathrm{N}$ in the soil, except in summer (August 2007 - Fig. 1). The temporal pattern of soil total inorganic $\mathrm{N}$ (Fig. 1b) therefore resembled that of $\mathrm{NO}_{3}^{-}$(Fig. 1c), reflecting the $\mathrm{N}$ additions in autumn when the three annual $\mathrm{N}$ additions had already been applied. In autumn, soils from fertilized plots had more inorganic $\mathrm{N}$ than the controls ( $40 \mathrm{~A}<40 \mathrm{AN}<80 \mathrm{AN}$ plots), corresponding to 11,22 and $32 \mu \mathrm{g}$ of $\mathrm{N} \mathrm{g}^{-1}$ of soil dwt more than the control (see materials and methods). After transforming the applied $\mathrm{N}$ doses ( 40 and $80 \mathrm{~kg} \mathrm{Nha}^{-1} \mathrm{yr}^{-1}$ ) into soil inorganic $\mathrm{N}$ concentrations (see materials and methods $-\mu \mathrm{g} \mathrm{g}^{-1}$ soil dwt), the comparison between the "total $\mathrm{N}$ added" and the "measured N" showed significant differences for the $40 \mathrm{~A}$ plots but not the $40 \mathrm{AN}$ and $80 \mathrm{AN}$ plots. Therefore, the $\mathrm{N}$ added to $40 \mathrm{AN}$ and $80 \mathrm{AN}$ plots appears to have been retained by the system, becoming detectable in soil total inorganic $\mathrm{N}$ measured in autumn. In $40 \mathrm{~A}$ plots the total soil inorganic $\mathrm{N}$ measured in autumn was significantly lower than the total $\mathrm{N}$ added (Table 2).

\subsection{Cistus ladanifer responses to $\mathbf{N}$ additions}

At the beginning of the experiment (spring 2007), C. ladanifer plant cover was similar in all treatments (Fig. 2a). However, differences between treatments were observed one year later, in spring 2008 (Fig. 2a, b). The $80 \mathrm{AN}$ treatment caused a decrease in the $C$. ladanifer (Dias et al., 2011) plant cover in relation to the control (Fig. 2b).

The $\mathrm{N}$ concentration of $C$. ladanifer leaves was also affected by the $\mathrm{N}$ form, since only the additions of ammonium nitrate ( $40 \mathrm{AN}$ and $80 \mathrm{AN}$ ) led to a significant increase in relation to the control (Fig. 3b). In contrast, the $\mathrm{N}$ concentration of $C$. ladanifer leaf litter responded to the $\mathrm{N}$ dose, with only the litter from the $80 \mathrm{AN}$ plots having significantly higher $\mathrm{N}$ concentrations than the control. The $\mathrm{C} / \mathrm{N}$ ratio of $C$. ladanifer leaves also depended significantly on the $\mathrm{N}$ form applied (Fig. 3c). 

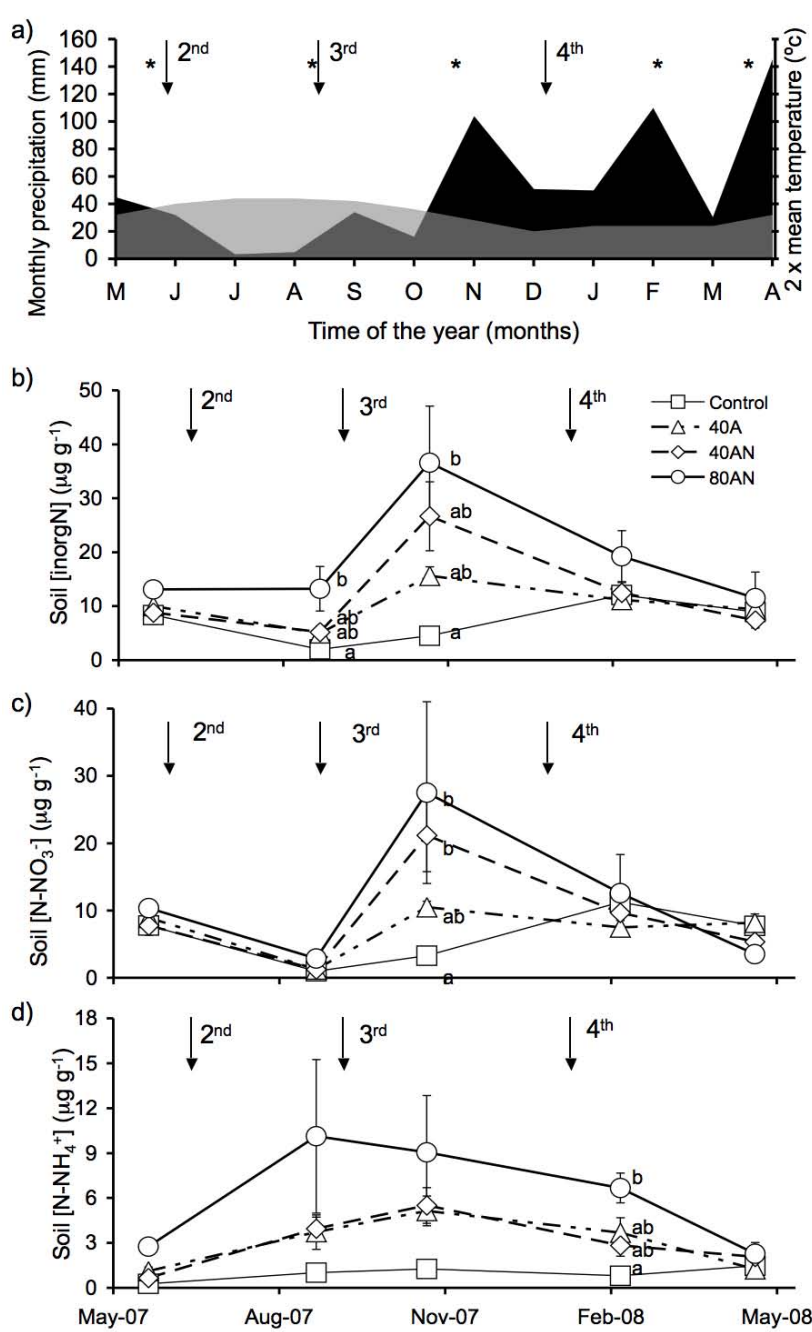

Fig. 1. Mean monthly temperature (grey), total monthly precipitation (black) and time of $\mathrm{N}$ additions (arrows) and soil sampling (asterisks) from May 2007 to May 2008 (a). Soil inorganic N (b), nitrate (c) and ammonium (d) concentrations according to the distinct $\mathrm{N}$ additions (Control, $40 \mathrm{~A}, 40 \mathrm{AN}$, and $80 \mathrm{AN}$ ). Different letters refer to statistically significant differences between the between treatments (ANOVA $p<0.05$ followed by a Bonferroni test). There were no significant interactions between treatment and time $(p<0.01)$. Values represent the mean $(n=3$ experimental plots per treatment) \pm SE.

\subsection{Components of soil inorganic $\mathrm{N}$ concentration in autumn}

To understand why soil inorganic $\mathrm{N}$ concentration was highest in autumn, the possible components of this $\mathrm{N}$ pool were assessed: inorganic $\mathrm{N}$ present in the soil in the previous season ([N] summer), the subsequent $\mathrm{N}$ addition ([N] addition) and the $\mathrm{N}$ present in the litter which was shed during the summer ([N] litter - see materials and methods). The $\mathrm{N}$ contained in $C$. ladanifer leaf litter produced in
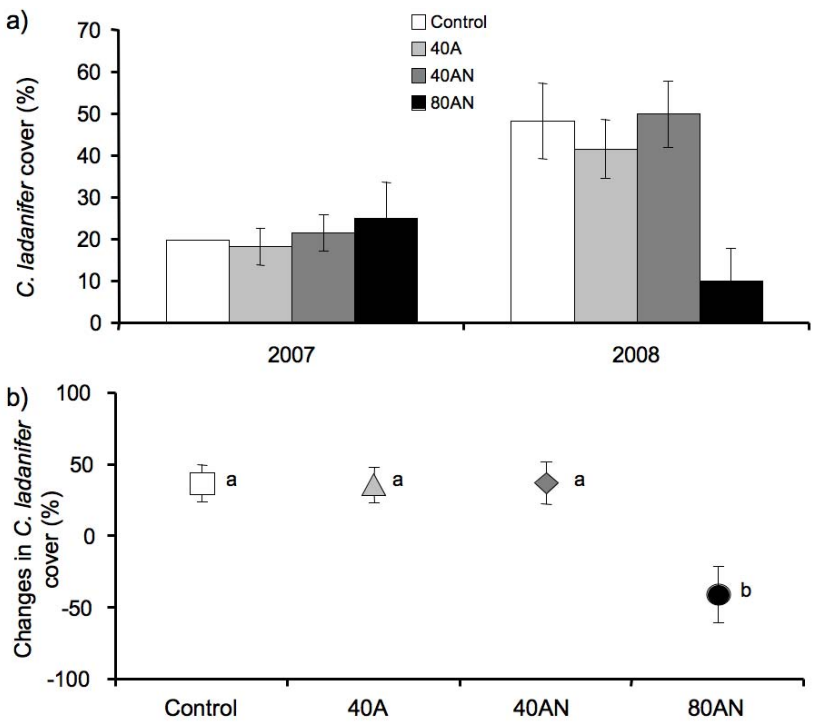

Fig. 2. C. ladanifer plant cover (a) and its response to the distinct $\mathrm{N}$ additions (Control, $40 \mathrm{~A}, 40 \mathrm{AN}$, and $80 \mathrm{AN}$ ). Plant cover (\%) was assessed on the first and second springs after the beginning of the $\mathrm{N}$ fertilizations, which allowed calculating its changes over time (see material and methods). Different letters refers to statistically significant differences between the two springs (ANOVA $p<0.1$ followed by a Bonferroni test). There were no significant interactions between treatment and time $(p<0.01)$. Values represent the mean $(n=3$ experimental plots per treatment $) \pm \mathrm{SE}$.

Table 2. Total $\mathrm{N}$ added to the soil over the first year of experiment (the first three $\mathrm{N}$ additions: January, April and August 2007) and the soil inorganic $\mathrm{N}$ concentrations in relation to the control determined in autumn (measured $\mathrm{N}$ ) according to the $\mathrm{N}$ treatments (40 A, $40 \mathrm{AN}$ and $80 \mathrm{AN})$.

\begin{tabular}{lrrr}
\hline N addition & $\begin{array}{r}\text { Total N added } \\
\left(\mu \mathrm{g} \mathrm{g}^{-1}\right)\end{array}$ & $\begin{array}{r}\text { Measured N } \\
\left(\mu \mathrm{g} \mathrm{g}^{-1}\right)\end{array}$ & \\
\hline $40 \mathrm{~A}$ & 20 & $11 \pm 2$ & $*$ \\
$40 \mathrm{AN}$ & 20 & $22 \pm 6$ & $\mathrm{~ns}$ \\
$80 \mathrm{AN}$ & 40 & $32 \pm 10$ & $\mathrm{~ns}$ \\
\hline
\end{tabular}

* Refers to significant differences between total $\mathrm{N}$ added and measured $\mathrm{N}$ (t-student $p<0.01)$. Values represent the mean $(n=3$ experimental plots per treatment $) \pm$ SE.

$40 \mathrm{~A}$ had $2.9 \mathrm{mg}$ more $\mathrm{N}$ per gram of litter than the control (data not shown), which corresponded to an addition of $3.5 \mu \mathrm{g} \mathrm{N} \mathrm{g}^{-1}$ soil (Fig. 4). Similarly, litter produced in $40 \mathrm{AN}$ and $80 \mathrm{AN}$ corresponded to the addition of 3.1 and $6.4 \mu \mathrm{g} \mathrm{N} \mathrm{g}^{-1}$ soil. When the three possible components of the autumn soil inorganic $\mathrm{N}$ concentration were combined as "calculated N", there were no significant differences between this and the "measured N". 

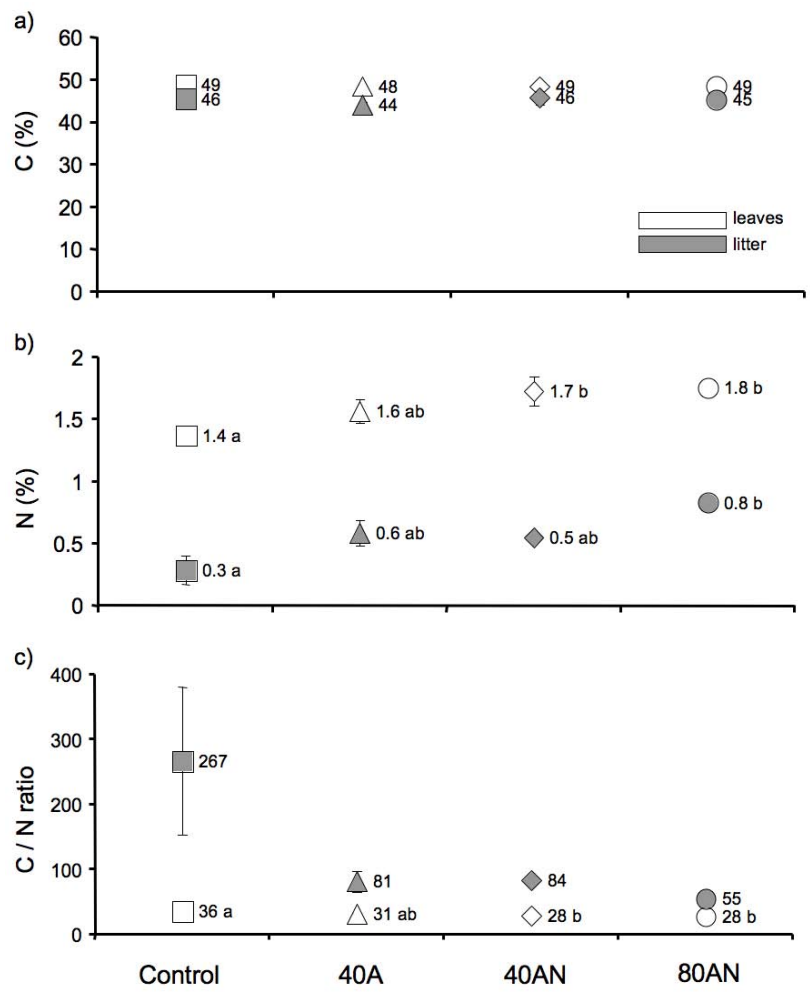

Fig. 3. $\mathrm{C}$ and $\mathrm{N}$ concentrations and the $\mathrm{C} / \mathrm{N}$ ratio of leaves and leaf litter of $C$. ladanifer in response to the distinct $\mathrm{N}$ additions (Control, $40 \mathrm{~A}, 40 \mathrm{AN}$ and $80 \mathrm{AN}$ ). Different letters refers to statistically significant differences between treatments (ANOVA $p<0.05$ followed by a Bonferroni test). Symbols and values represent the mean $(n=3$ experimental plots per treatment) \pm SE.

\section{Discussion}

\subsection{Short-term response of a Mediterranean soil to N enrichment}

Soil fertility of the Mediterranean Basin is considered to be moderate to high within Mediterranean-type ecosystems (Cowling et al., 1996). However, soils at the experimental site (Table 1) had lower $\mathrm{N}$ concentration than those reported in other studies in the Mediterranean Basin (e.g. $>0.16 \%$, Gallardo et al., 2000; $>0.4 \%$, Ferran et al., 2005; $>0.2 \%$, Sardans et al., 2008; $>0.2 \%$, Rutigliano et al., 2009). The level of extractable $P$ was low in comparison with other Mediterranean Basin soils ( $>12 \mu \mathrm{g} \mathrm{g}^{-1}$, Dumontet et al., 1996; $>7 \mu \mathrm{g} \mathrm{g}^{-1}$, Carreira et al., 1997; $>7 \mu \mathrm{g} \mathrm{g}^{-1}$, Ferran et al., 2005; $>30 \mu \mathrm{g} \mathrm{g}^{-1}$, Saura-Mas et al., 2009) but comparable with those from Australian and South African Mediterranean-type ecosystems (Milewski, 1983; Mitchell et al., 1984; Hobbs, 1995). Soil organic matter values were within the range observed in other Mediterranean Basin soils (Peñuelas et al., 1999; Gallardo et al., 2000; Cruz et al., 2008) but so low that these soils are at risk of desertification
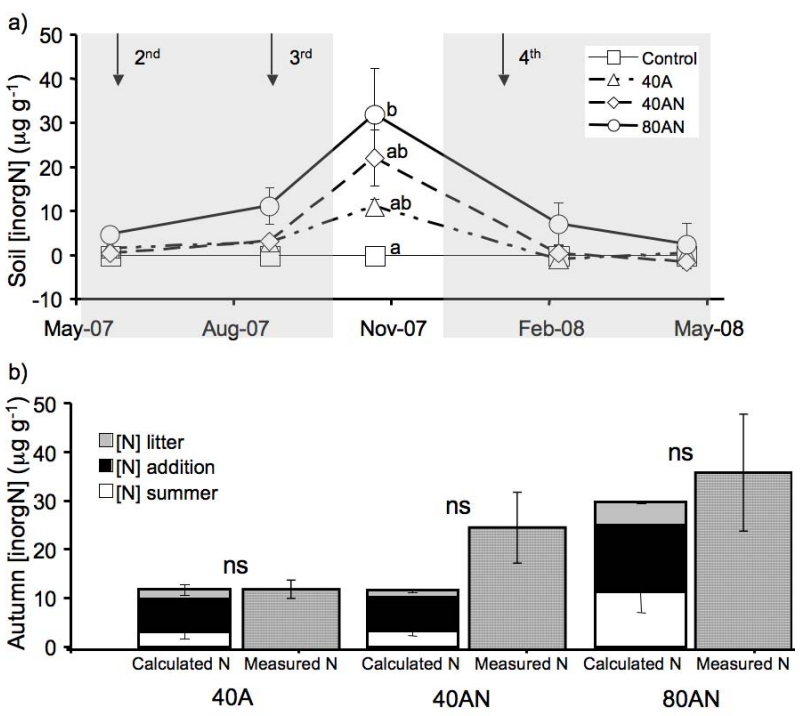

Fig. 4. Soil inorganic $\mathrm{N}$ concentration in relation to the control along the experimental period in response to distinct $\mathrm{N}$ additions (a - see material and methods) and comparison between the "calculated N" (stacked columns - see material and methods) and the "measured N" (dashed columns) concentrations of soil inorganic N in autumn and according to the $\mathrm{N}$ additions (40 A, $40 \mathrm{AN}$ and $80 \mathrm{AN}$ -b). There were no significant differences between "calculated N" and "measured N" (t-student $p<0.001$ ). Values represent the mean $(n=3$ experimental plots per treatment $) \pm \mathrm{SE}$.

due to soil erosion (López-Bermúdez and García-Gómez, 2006). Soil acidification (Table 1) is among the most commonly reported effects of $\mathrm{N}$ enrichment and may result from cation loss, aluminium release and nitrification. Although soils at the experimental site were slightly acidic, nitrification occurred since $\mathrm{NO}_{3}^{-}$was the predominant $\mathrm{N}$ source present in the soil, even in the treatments where $\mathrm{N}$ was added as $\mathrm{NH}_{4}^{+}$ (Fig. 1). However, soil acidification tends to be less intense in soils of the Mediterranean Basin than in other ecosystems, due to their high cation exchange capacity and alkaline sands blown in from North Africa (Ochoa-Hueso et al., 2011).

Many studies of soil inorganic $\mathrm{N}$ availability have sampled soils in spring, when water and temperature do not limit biological activities (Fig. 1a), and conditions are optimal for plant growth, leading to the conclusion that values obtained could be used as indicators of the system's $\mathrm{N}$ availability. However, comparison of soil inorganic $\mathrm{N}$ concentrations determined in the two consecutive springs (2007 and 2008) showed no differences between treatments or between years (Fig. 1b) thus constituting a baseline of inorganic $\mathrm{N}$ availability for the ecosystem. This may imply that the $\mathrm{N}$ added to the system was either lost $\left(\mathrm{NO}_{3}^{-}\right.$leaching, runoff, $\mathrm{NH}_{4}^{+}$ volatilization, denitrification) or incorporated in the biota (microbial community and vegetation). If most of the added $\mathrm{N}$ had been lost from the system, the peak of soil inorganic $\mathrm{N}$ observed in autumn (Fig. 1b) should only reflect (if at all) 
the previous $\mathrm{N}$ addition (summer 2007). However, the observed increase in soil inorganic $\mathrm{N}$ in autumn was related not only to the previous $\mathrm{N}$ addition, but also with the "total $\mathrm{N}$ added" at that sampling time (Table 2). The mild temperatures and the adequate water availability (Fig. 1a) may have stimulated the decomposition of the large litter input derived from the leaf shedding of summer semi deciduous plants (Correia, 1988) and the death of annual plants in the summer. In fact, $\mathrm{N}$ mineralization has been shown to peak in early autumn in Mediterranean maquis soils (Rutigliano et al., 2009; Simões et al., 2009). Thus, the reduced biological activity in the summer that allowed inorganic $\mathrm{N}$ to accumulate, combined with the summer $\mathrm{N}$ fertilization and the high autumn N mineralization (Rutigliano et al., 2009), all appear to contribute to the peak of soil inorganic $\mathrm{N}$ in autumn (Fig. 4). The inorganic $\mathrm{N}$ concentrations detected in the soil in autumn suggest that the ecosystem was more efficient in retaining $\mathrm{N}-\mathrm{NH}_{4} \mathrm{NO}_{3}$ than solely $\mathrm{N}-\mathrm{NH}_{4}^{+}$. This shows that although undetectable as soil inorganic $\mathrm{N}$ along the year, most of the added $\mathrm{N}$ was used and conserved in the system as would be expected in a nutrient limited ecosystem (Craine, 2009). These results clearly show that early autumn is the best time of the year to measure soil inorganic $\mathrm{N}$ as an indicator of the $\mathrm{N}$ fluxes between the biotic and abiotic compartments. The $\mathrm{N}$ incorporation into the biotic compartments is in agreement with the fast responses of the ecosystem structure and function to increased $\mathrm{N}$ availability (Dias et al., 2011). If a large fraction of the $\mathrm{N}$ added to the system is moving through the biotic and abiotic compartments of the ecosystem, then large impacts on ecosystem processes can be expected (e.g. Emmett, 2007; Bobbink et al., 2010).

\subsection{Short-term response of the plant community to $\mathrm{N}$ additions}

The cover of $C$. ladanifer (a slow growing conservative species) (Dias et al., 2011) increased under all treatments except 80 AN (Fig. 2). In nutrient limited ecosystems, $\mathrm{N}$ additions tend to induce changes in the plant community promoting a decrease in the plant cover of the slow growing species and an increase in that of the fast growing species.

Under conditions of nutrient limitation, the efficiency of a plant using limiting nutrients depends not only on the uptake efficiency but also on the retention time (Emmett, 2007). Accordingly, the $\mathrm{N}$-driven response of the $\mathrm{N}$ concentration in C. ladanifer's leaves points to this species' efficient $\mathrm{N}$ uptake (Fig. 3b) and was in agreement with the use of plant tissue $\mathrm{N}$ concentration as a $\mathrm{N}$ accumulation indicator (Sutton et al., 2005). However, if plants were only $\mathrm{N}$ limited, the extra $\mathrm{N}$ would have been used to produce biomass so that the $\mathrm{N}$ content would have increased but not the $\mathrm{N}$ concentration. Thus, increased leaf $\mathrm{N}$ concentration together with decreased soil $\mathrm{P}$ concentration (Table 1) may indicate $\mathrm{N}$ and $\mathrm{P}$ co-limitation (Bishop et al., 2010). On the other hand, plants characteristic of nutrient-poor ecosystems have efficient ways of reabsorbing nutrients from old leaves (Craine, 2009), depriving the litter of $\mathrm{N}$ and giving rise to high $\mathrm{C} / \mathrm{N}$ ratios in the litter (litter from control plots - Fig. 3c). As the $\mathrm{N}$ limitation was alleviated by the $\mathrm{N}$ additions, the $\mathrm{N}$ resorption efficiency from the old leaves may have decreased (Kobe et al., 2005), resulting in increased $\mathrm{N}$ concentration in the litter (Fig. 3b), i.e. improved litter quality (Witkowski, 1989; O'Connel and Grove, 1993; Vourlitis et al., 2009). The overall N-driven response of leaf and litter $\mathrm{N}$ concentrations and the $\mathrm{C} / \mathrm{N}$ ratio was similar to that observed in two other Mediterraneantype ecosystems with different plant communities: one dominated by summer semi deciduous (coastal sage scrub), the other by evergreen sclerophylls (chaparral - Vourlitis et al., 2007; Vourlitis and Pasquini, 2009). Therefore, litter N concentration should be a good indicator of the $\mathrm{N}$ availability in Mediterranean-type ecosystems.

\subsection{N cycling through biotic and abiotic compartments}

Combined analysis of the soil inorganic $\mathrm{N}$ concentrations (Fig. 1) and the changes in the $\mathrm{N}$ concentration (and $\mathrm{C} / \mathrm{N}$ ratio) of $C$. ladanifer leaves and litter (Fig. 3) suggest that under these Mediterranean conditions, the $\mathrm{N}$ cycling through biotic and abiotic compartments allowed soil inorganic $\mathrm{N}$ to reflect cumulative $\mathrm{N}$ additions in autumn (Fig. 1b). This suggests that the $\mathrm{N}$ added to the system is rapidly taken up by the biota and it is only after leaf shedding in summer and litter decomposition in autumn that the added $\mathrm{N}$ is detectable in the soil. The fact that there were no differences between the soil inorganic $\mathrm{N}$ in $40 \mathrm{AN}$ and $80 \mathrm{AN}$ plots and the respective total $\mathrm{N}$ added (Table 2) can only be explained by efficient internal cycling of the previously added $\mathrm{N}$ within the ecosystem. If the soil sampling had occurred in late autumn it is likely that the peak in soil inorganic $\mathrm{N}$ availability would be missed, since the $\mathrm{N}$ concentration in $C$. ladanifer litter increases through the autumn and winter (Simões et al., 2009). The retention of $\mathrm{N}$ by litter has also been shown in other Mediterranean communities (e.g. Fioretto et al., 2005; Holub and Lajtha, 2004), and could help explain the sharp decline in soil inorganic $\mathrm{N}$ availability in winter (Fig. 1b).

An inverse relationship between litter $\mathrm{C} / \mathrm{N}$ ratio and decomposition rate (Bosatta and Staaf, 1982; Taylor et al., 1989) has also been established for Mediterranean plant species (Rutigliano et al., 2009), so that the $\mathrm{N}$-driven lower litter $\mathrm{C} / \mathrm{N}$ ratio (Fig. 3c) may have stimulated decomposition. Also, the decomposition of higher quality litter has been shown to result in a rapid ( $\sim 2$ months) increase of inorganic N (Sirulnik et al., 2007). Litter decomposition, together with the soil inorganic $\mathrm{N}$ concentration in the summer and the following $\mathrm{N}$ addition contributed to the observed autumn inorganic N (Fig. 4), explaining the inorganic N concentrations measured in autumn. Litter decomposition may be an important component of the soil inorganic $\mathrm{N}$ measured in autumn. Data suggest that living plants and litter have a crucial role in preventing $\mathrm{N}$ losses from Mediterranean maquis. 


\section{Conclusions}

The results of this study suggest that most of the added inorganic $\mathrm{N}$ was retained in this $\mathrm{N}$-limited Mediterranean maquis, affecting its structure and function. Also, the form of the added $\mathrm{N}$ influenced the overall $\mathrm{N}$ retention during the study period: $\mathrm{NH}_{4}^{+}$additions resulted in lower $\mathrm{N}$ recovery from the soil than the additions of $\mathrm{NH}_{4} \mathrm{NO}_{3}$. The added $\mathrm{N}$ was retained in the biotic compartment during the growth season, then returned to the soil after the dry period through litter decomposition (autumn). The data highlight the sensitivity of Mediterranean Basin ecosystems, which constitute an important worldwide biodiversity hotspot, to $\mathrm{N}$ deposition. Thus, the present $\mathrm{N}$-manipulation study points to the role of $\mathrm{N}$ availability as a driving force for biodiversity changes, especially in Natura 2000 sites such as this manipulation site. However, caution should be used when extrapolating data to other Mediterranean-type ecosystems, which may differ in soil fertility, and even to other Mediterranean habitats that differ in plant community. Finally, this is the first integrated field study of how European Mediterranean ecosystems retain $\mathrm{N}$ enrichment of different forms and doses, however longer-term studies are needed to explore the generality of these observations.

Acknowledgements. This study was supported by the Fundação para a Ciência e Tecnologia (FCT) through the project PTDC/BIABEC/099323/2008 and PhD grant BD/25382/2005 to Teresa Dias. We are grateful to Arrábida Natural Park for making the experimental site available and allowing the $\mathrm{N}$ manipulation experiment to which this paper refers. Finally we are grateful to Steve Houghton for helping with the manuscript's preparation and to the three anonymous reviewers whose comments and suggestions greatly improved the present paper.

Edited by: S. Reis and J. Sprent

\section{References}

Augustine, D. J. and McNaughton, S. J.: Temporal asynchrony in soil nutrient dynamics and plant production in a semiarid ecosystem, Ecosystems., 7, 829-840, 2004.

Bishop, J. G., O’Hara, N. B., Titus, J. H., Apple, J. L., Gill, R. A., and Wynn, L.: N-P co-limitation of primary production and response of arthropods to $\mathrm{N}$ and $\mathrm{P}$ in early primary succession on Mount St. Helens volcano, PlosOne, 510, 1-9, 2010.

Bobbink, R., Hornung, M., and Roelofs, J. G. M.: The effects of air-borne nitrogen pollutants on species diversity in natural and semi-natural European vegetation, J. Ecol., 86, 717-738, 1998.

Bobbink, R., Hicks, K., Galloway, J., Spranger, T., Alkemade, R., Ashmore, M., Bustamante, M., Cinderby, S., Davidson, E., Dentener, F., Emmett, B., Erisman, J.-W., Fenn, M., Gilliam, F., Nordin, A., Pardo, L., and De Vries, W.: Global assessment of nitrogen deposition effects on terrestrial plant diversity: a synthesis, Ecol. Appl., 20, 30-59, 2010.

Bosatta, E. and Staaf, H.: The control of nitrogen turnover in forest litter, Oikos, 39, 143-151, 1982.
Brooks, P. D., Williams, M. W., and Schmidt, S. K.: Inorganic nitrogen and microbial biomass dynamics before and during spring snowmelt, Biogeochemistry, 43, 1-15, 1998.

Carreira, J. A., Lajtha, K., and Niell, F. X.: Phosphorus transformations along a soil/vegetation series of fire-prone, dolomitic, semiarid shrublands of southern Spain, Biogeochemistry, 39, 87-120, 1997.

Cassman, K. G., Dobermann, A., Walters, D. T., and Yang, H.: Meeting cereal demand while protecting natural resources and improving environmental quality, Annu. Rev. Env. Resour., 28, 315-358, 2003.

Correia, O. A.: Contribuição da fenologia e ecofisiologia em estudos da sucessão e dinâmica da vegetação mediterrânica, $\mathrm{PhD}$ thesis, Dep. de Biol. Veget., Universidade de Lisboa, Lisboa, Portugal, 1988 (in Portuguese).

Correia, O. A. and Catarino, F. M.: Seasonal changes in soil-to-leaf resistance in Cistus sp. and Pistacea lentiscus, Acta Oecol., 15, 289-300, 1994.

Cowling, R. M., Rundel, P. W., Lamont, B. B., Arroyo, M. K., and Arianoutsou, M.: Plant diversity in Mediterranean-climate regions, Tree, 11, 362-366, 1996.

Craine, J. M.: Resource strategies of wild plants, Princeton University Press, Princeton and Oxford, 2009.

Cruz, C. and Martins-Loução, M. A.: Nitrogen in a sustainable environment: a matter of integration, in: Nitrogen in a sustainable ecosystem, edited by: Martins-Loução, M. A. and Lips, S. H., Backhuys, The Netherlands, 415-419, 2000.

Cruz, C., Bio, A. M. F., Jullioti, A., Dias, T., and Martins-Loução, M. A.: Heterogeneity of soil surface ammonium concentration and other characteristics, related to plant specific variability in a Mediterranean-type ecosystem, Environ. Pollut., 154, 414-423, 2008.

de Schrijver, A., Verheyen, K., Mertens, J., Staelens, J., Wuyts, K., and Muys, B.: Nitrogen saturation and net ecosystem production, Nature, 451, E1, doi:10.1038/nature06578, 2008.

Dias, T., Malveiro, S., Martins-Loução, M. A., Sheppard, L. J., and Cruz, C.: Linking N-driven biodiversity changes with soil N availability in a Mediterranean ecosystem, Plant Soil, 34, 125136, doi:10.1007/s11104-010-0628-3, 2011.

Dumontet, S., Dinel, H., Scopa, A., Mazzatura, A., and Saracino, A.: Post-fire soil microbial biomass and nutrient content of a pine forest soil from a dunal Mediterranean environment, Soil Biol. Biochem., 28, 1467-1475, 1996.

Emmett, B. A.: Nitrogen saturation of terrestrial ecosystems: some recent findings and their implications for our conceptual framework, Water Air Soil Poll.: Focus, 7, 99-109, 2007.

Fenn, M. E., Baron, J. S., Allen, E. B., Rueth, H. M., Nydick, K. R., Geiser, L., Bowman, W. D., Sickman, J. O., Meixner, T., Johnson, D. W., and Neitlich, P.: Ecological effects of nitrogen deposition in the western United States, Bioscience, 53, 404420, 2003.

Ferran, A., Delitti, W., and Vallejo, V. R.: Effects of fire recurrence in Quercus coccifera L. shrublands of the Valencia Region (Spain): II. Plant and soil nutrients, Plant Ecol., 177, 71-83, 2005.

Fioretto, A., Di Nardo, C., Papa, S., and Fuggi, A.: Lignin and cellulose degradation and nitrogen dynamics during decomposition of three leaf litter species in a Mediterranean ecosystem, Soil Biol. Biochem., 37, 1083-1091, 2005. 
Gallardo, A., Rodríguez-Saucedo, J. J., Covelo, F., and FernándezAlés, R.: Soil nitrogen heterogeneity in a Dehesa ecosystem, Plant Soil, 222, 71-82, 2000.

Galloway, J. N., Townsend, A. R., Erisman, J. W., Bekunda, M., Cai, Z., Freney, J. R., Martinelli, L. A., Seitzinger, S. P., and Sutton, M. A.: Transformations of the nitrogen cycle: recent trends, questions, and potential solutions, Science, 320, 889-892, 2008.

Hobbs, R. J., Richardson, D. M., and Davis, G. W.: Mediterraneantype ecosystems: opportunities and constraints for studying the function of biodiversity, in: Mediterranean-type ecosystems: the function of biodiversity, edited by: Davis, G. W. and Richardson, D. M., Springer, Heidleberg, 1-42, 1995.

Holub, S. M. and Lajtha, K.: The fate and retention of organic and inorganic ${ }^{15} \mathrm{~N}$ nitrogen in an old-growth forest soil in western Oregon, Ecosystems, 7, 368-380, 2004.

Jackson, L. E., Strauss, R. B., Firestone, M. K., and Bartolome, J. W.: Plant and soil nitrogen dynamics in California annual grassland, Plant Soil, 110, 9-17, 1988.

Jaeger III, C., Monson, R., Fisk, M., and Schmidt, S.: Seasonal partitioning of nitrogen by plants and soil microorganisms in an alpine ecosystem, Ecology, 80, 1883-1891, 1999.

Kobe, R. K., Lepczyk, C. A., and Iyer, M.: Resorption efficiency decreases with increasing green leaf nutrients in a global data set, Ecology, 86, 2780-2792, 2005.

López-Bermúdez, F. and García-Gómez, J.: Desertification in the arid and semiarid Mediterranean regions. A food security issue, in: Desertification in the Mediterranean region. A security issue, edited by: Kepner, W. G., Rubio, J. L., Mouat, D. A., and Pedrazzini, D. A., Springer, the Netherlands, 401-428, 2006.

Matsumura, S. and Witjaksono, G.: Modification of the Cataldo method for the determination of nitrate in soil extracts by potassium chloride, Soil Sci. Plant Nutr., 45, 231-235, 1999.

Meixner, T. and Fenn, M. E.: Biogeochemical budgets in a Mediterranean catchment with high rates of atmospheric $\mathrm{N}$ deposition importance of scale and temporal asynchrony, Biogeochemistry, 70, 331-356, 2004.

Milewski, A. V.: A comparison of ecosystems in Mediterranean Australia and Southern Africa: nutrient-poor sites at the barrens and the Caledon coast, Annu. Rev. Ecol. Syst., 14, 57-76, 1983.

Mitchell, D. T., Brown, G., and Jongens-Roberts, S. M.: Variation of forms of phosphorus in the sandy soils of coastal fynbos, south-western Cape, J. Ecol., 72, 575-584, 1984.

Ochoa-Hueso, R., Allen, E. B., Branquinho, C., Cruz, C., Dias, T., Fenn, M. E., Manrique, E., Perez-Corona, M. E., Sheppard, L. J., and Stock, W. D.: Nitrogen effects on Mediterranean-type ecosystems: an ecological assessment, Environ. Pollut., 159, 2265-2279, doi:10.1016/j.envpol.2010.12.019, 2011.

Peñuelas, J., Filella, I., and Terradas, J.: Variability of plant nitrogen and water use in a 100-m transect of a subdesertic depression of the Ebro valley (Spain) characterized by leaf $\delta^{13} \mathrm{C}$ and $\delta^{15} \mathrm{~N}$, Acta Oecol., 20, 119-123, 1999.

Phoenix, G. K., Hicks, W K., Cinderby, S., Kuylenstierna, J. C. I., Stock, W. D., Dentener, F. J., Giller, K. E., Austin, A. T., Lefroy, R. D. B., Gimeno, B. S., Ashmore, M. R., and Ineson, P.: Atmospheric nitrogen deposition in world biodiversity hotspots: the need for a greater global perspective in assessing $\mathrm{N}$ deposition impacts, Glob. Chang. Biol., 12, 470-476, 2006.
Rivas-Martínez, S., Penas, A., and Díaz, T. E.: Bioclimatic map of Europe- Thermoclimatic belts, University of León, Spain, available at: http://www.globalbioclimatics.org/form/tb med.htm, last access: January 2010, 2004.

Rutigliano, F. A., Castaldi, S., D’Ascoli, R., Papa, S., Carfora, A., Marzaioli, R., and Fioretto, A.: Soil activities related to nitrogen cycle under three plant cover types in Mediterranean environment, Appl. Soil Ecol., 43, 40-46, 2009.

Sardans, J., Peñuelas, J., Estiarte, M., and Prieto, P.: Warming and drought alter $\mathrm{C}$ and $\mathrm{N}$ concentration, allocation and accumulation in a Mediterranean shrubland, Glob. Change Biol., 14, 23042316, 2008.

Saura-Mas, S. and Lloret, F.: Linking post-fire regenerative strategy and leaf nutrient content in Mediterranean woody plants, Perspect. Plant Ecol., 11, 219-229, 2009.

Schultz, J.: The ecozones of the world: the ecological divisions of the geosphere, Springer, the Netherlands, 2002.

Sheppard, L. J., Leith, I. D., Crossley, A., van Dijk, N., Fowler, D., Sutton, M. A., and Woods, C.: Stress responses of Calluna vulgaris to reduced and oxidised $\mathrm{N}$ applied under "real world conditions", Environ. Pollut., 154, 404-413, 2008.

Simões, M. P., Madeira, M., and Gazarini, L.: Ability of Cistus L. shrubs to promote soil rehabilitation in extensive oak woodlands of Mediterranean areas, Plant Soil, 323, 249-265, 2009.

Sirulnik, A. G., Allen, E. B., Meixner, T., and Allen, M. F.: Impacts of anthropogenic $\mathrm{N}$ additions on nitrogen mineralization from plant litter in exotic annual grasslands, Soil Biol. Biochem., 39, 24-32, 2007.

Sutton, M. A., Pitcairn, C. E. R., Leith, I. D., Sheppard, L. J., van Dijk, N., Tang, Y. S., Skiba, U., Smart, S., Mitchell, R., Wolseley, P., James, P., Purvis, W., and Fowler, D.: Bioindicator and biomonitoring methods for assessing the effects of atmospheric nitrogen on statutory nature conservation sites, edited by: Sutton, M. A., Pitcairn, C. E. R., and Whitfield, C. P., JNCC Report No: 356, 2004.

Taylor, B. R., Parkinson, D., and Parsons, W. F. J.: Nitrogen and lignin content as predictors of litter decay rates: a microcosm test, Ecology, 70, 97-104, 1989.

Vourlitis, G. L. and Pasquini, S.: Experimental dry-season N deposition alters species composition in southern Californian Mediterranean-type shrublands, Ecology, 90, 2183-2189, 2009.

Vourlitis, G. L., Pasquini, S., and Zorba, G.: Plant and soil N response of southern Californian semi-arid shrublands after 1 year of experimental N deposition, Ecosystems, 10, 263-279, 2007.

Vourlitis, G. L., Pasquini, S., and Mustard, R.: Effects of dry-season $\mathrm{N}$ input on the productivity an $\mathrm{N}$ storage of Mediterranean-type shrublands, Ecosystems, 12, 473-488, 2009.

Witkowski, E. T. F.: Effects of nutrient additions on litter production and nutrient return in a nutrient-poor Cape fynbos ecosystem, Plant Soil, 117, 227-235, 1989. 